\title{
PENDAMPINGAN PEMBELAJARAN BAHASA ARAB ASPEK MAHÂRATUL KALÂM MELALUI METODE MUBASYARAH DI PONDOK PESANTREN AL - IKHLAS MUHAMMADIYAH BIMA
}

\author{
Nurul Zuhriyah dan Ade Rahman \\ (zuhriyahhnurul@gmail.com \& Aderahman0842@gmail.com)
}

(Dosen Tetap Prodi PBA fakultas Tarbiyah

IAI Muhammadiyah Bima)

\author{
الملخصص \\ حلولا بمشكلاتهم عن اللغة العريية حصوصا في مهارة الكلام. استخدم الطربقة \\ المشاركة النشطة، بكيفبة اشتراكة طلبة من الفصل المعين. ومن التنائجها: (). هذه \\ الطر:قة المباشرة تجري فعالا ليدافعون الطلبة في تكلم اللغة العربية ب). هذه الطربقة \\ جعل ارتفاعات القدرة الطلبة إلى درجة جيدة، ويتضحها بحفظ المفردات، الشجاعاة \\ عند إجابة السؤال وفهم الحوار. وأما مشكلاتها: (). هذه الأنشطة يتجنب بالأنشطة \\ الأخرى r). ونقص إهتمام بعض الطلبة.
}

\section{الكلمات المفتاح: مهارة الكلام, الطربقة المشاركة النشطة}

Pengabdian ini dilakukan untuk memberikan pendampingan pada santriwan dan santriwati pondok pesantren Al-Ikhlas Muhammadiyah Bima, yang berkaitan dengan hambatan penerapan bahasa Arab pada aspek maharatul kalam dengan metode Partisipasi aktif yaitu dengan mengikut sertakan santri dari kelas yang sudah ditentukan untuk mengikuti pembinaan secara maksimal. Adapun hasil dari penggunaan metode ini adalah: 1). Metode mubasyarah yang dipergunakan dalam pendampingan ini sangatlah efektif untuk membuat santri berani berbicara selama pembelajaran berlangsung. 2). Kemampuan berbahasa Arab rata rata santri yang mengikuti pembinaan ini meningkat yang dibuktikan dengan hafalan mufrodat, keberanian menjawab soal dan pemahaman terhadap hiwar. Adapun faktor penghambat berjalanya kegiatan ini adalah: 1). Jadwal pendampingan yang sering bersamaan dengan jadwal kegiatan lain, 2). kurangnya kesadaran sebagian santri untuk mengikuti kegiatan ini.

\section{Kata Kunci: Mahâratul Kalâm, Metode Mubasyarah.}




\section{A. PENDAHULUAN}

Pondok Pesantren merupakan basis pendidikan keislaman yang sangat kuat.Itu sebabnya pesantren sampai saat ini sangat diminati oleh masyarakat untuk menitipkan anak anaknya belajar. Selain belajar ilmu-ilmu agama para santri juga belajar ilmuilmu umum dan juga ilmu- ilmu bahasa. Sebagai lembaga Islam, maka bahasa pengantar yang kerap dipakai setiap harinya adalah bahasa arab. Karena sebagian kitab atau buku buku yang mereka pelajari kebanyakan adalah menggunakan bahasa arab. Sehingga bahasa arab bagi pondok pesantren adalah kebutuhan yang tidak bisa terelakkan.

Walaupun masih ada sebagian pondok pesantren yang belum mewajibkan para santrinya mengggunakan bahasa Arab. Sebagaimana kita ketahui urgensi bahasa Arab sangatlah berperan besar dalam menumbuhkan kultur keislaman yang ada dipesantren. Merujuk pada pengertian bahasa pada dasarnya adalah suatu sistem symbol vocal atau visual yang bersifat arbiter, yang digunakan oleh suatu masyarakat sebagai sarana untuk melakukan urusan sehari hari mereka. ${ }^{1}$ Bisa disimpulkan bahwa tujuan mempelajari suatu bahasa (Arab) ialah agar bisa berkomunikasi menggunakan bahasa tersebut. Pendapat ini dikuatkan Basiran, bahwa tujuan pembelajaran bahasa adalah keterampilan komunikasi. ${ }^{2}$ Prinsip komunikasi merupakan prinsip yang paling penting karena meyakini bahwa tujuan pembelajaran bahasa arab adalah kemampuan dalam menggunakan bahasa sebagai alat komunikasi. Kemampuan ini dapat dicapai dengan memberikan perhatian pada pengguna bahasa bukan pada kaidah bahasa, tapi lebih kepada penerapan pada kegiatan setiap harinya. Sehingga ketika mempelajari bahasa Arab maka keterampilan dasar yang menjadi tujuan utama adalah kemahiran berbicara, disamping dari tujuan-tujuan lainnya. Tetapi fakta yang terjadi adalah masih banyak dari proses pembelajaran bahasa arab masih belum menunjukkan signifikasi yang sangat baik dalam praktiknya. Kondisi serupa ditemukan pada lembaga pesantren seperti yang telah diungkapkan diatas, terutama yang di identifikasi sebagai pesantren tradisional.

Sehingga Sekalipun hampir semua mengetahui arti penting penguasaan bahasa arab, akan tetapi kesadaran untuk mempelajarinya tidak selalu berjalan

1. M. Zaka Al Farisi, Pedoman penerjemahan Arab-Indonesia, (Bandung: Remaja Rosdakarya, 2014), 32

2. Asna Andriani, Urgensi Pembelajaran Bahasa, TA'ALLUM,Vol. 03, No. 01, Juni 2015 
secara linear, sehingga ada beberapa hal yang membuat bahasa Arab itu sendiri menjadi sangat kurang diminati oleh para santri di pesantren tersebut. Adapun alasan-alasan yang menyertainya sebagai berikut: Pertama, Terdapat kendala psikologis berupa ketakutan untuk mempelajarinya. Kedua, Minimnya akses terhadap pemahaman tentang bahasa asing itu sendiri. Ketiga, Kurangnya sumber daya manusia yang memadai untuk mengembangkan bahasa arab. ${ }^{3}$. Keempat, Faktor lingkungan sosial yang kurang kondusif. Kelima, Kurangnya pemanfaatan sarana dan prasarana di dalam proses pembelajaran ${ }^{4}$.

Dalam hal ini peneliti mencoba untuk menelaah lebih dekat hal tersebut pada salah satu Pondok Pesantren di Kota Bima yaitu Pondok Pesantren Al- Ikhlas Muhammadiyah Bima. Setelah dilakukan beberapa tes dan wawancara mendalam mengenai masalah dasar kebutuhan berbahasa yang dihadapi oleh kebanyakan santri maka didapati pernyataan sebagai berikut: "Kami ingin sekali menggunakan bahasa arab dipondok, tetapi apalah daya kebanyakan dari santriwan dan santriwati lebih aktif menggunakan bahasa Bima dan itu sudah menjadi kebiasaan setiap hari, padahal sudah dilarang oleh ustaz, sebagian teman teman ada yang lumayan semangat belajar bahasa Arab." 5 ujar salah satu santri.

Dengan demikian tim pengabdiankepada masyarakat menyimpulkan bahwa kondisi yang paling penting untuk ditangani adalah bagaimana mereka agar bisa mengerti dan berbicara mengunakan bahasa Arab, mereka membutuhkan dukungan dan motivasi yang tinggi membangun budaya berbahasa arab di lingkungannya. Sehingga dalam hal ini tim merasa perlu memberikan pelatihan pendampingan untuk meningkatkan kompetensi berbicara bahasaArab (maharatul kalam) dengan langkah-langkah sebagai berikut:

3 . https://jongbintoro.wordpress.com. Diakses pada 10 Juni 2019.

${ }^{4}$. Fathul Mujib dan Nailurrahmawati, Metode Permainan Edukatif Dalam Bahasa Arab, (Jogjakarta, Diva Press, 2011), 8

5 . Abu Bakar, Wawancara, (Ponpes Al - Ikhlas Muhammadiyah Bima), 3 Agustus 2019 


\section{Pembinaan}

Pembinaan berasal dari kata bina, yang mendapat imbuhan pe-an, sehingga menjadi kata pembinaan. Pembinaan adalah usaha, tindakan, dan kegiatan yang dilakukan secara efisien dan efektif untuk memperoleh hasil yang lebih baik. Pembinaan merupakan proses, cara membina dan penyempurnaan atau untuk para santri di Pondok Pesantren Al Ikhlas Muhammadiyah Bima agar lebih giat lagi dalam mempelajari bahasa arab khususnya pada aspek kemampuan berbicara karena hal itu adalah yang paling utama. Bagi para Pembina pondok pesantren Al Ikhlas Muhammadiyah Kota Bima agar lebih terpacu dalam meningkatkan minat belajar bahasa arab santri dan memperbaiki tatanan kebahasaan serta peraturan yang ada di asrama.

Pembinaan pada dasarnya merupakan aktivitas atau kegiatan yang dilakukan secara sadar, berencana, terarah, dan teratur secara bertanggung jawab dalam rangka penumbuhan, peningkatan dan pengembangan kemampuan serta sumbersumber yang tersedia untuk mencapai tujuan. Pertama, Pembinaan adalah upaya pendidikan formal maupun non formal yang dilakukan secara sadar, berencana, terarah, teratur, dan bertanggung jawab dalam rangka memperkenalkan, menumbuhkan, membimbing, dan mengembangkan suatu dasar-dasar kepribadian yang seimbang, utuh dan selaras, pengetahuan dan keterampilan sesuai dengan bakat, kecenderungan/keinginan serta kemampuan-kemampuannya sebagai bekal, untuk selanjutnya atas perkasa sendiri menambah, meningkatkan dan mengembangkan dirinya, sesamanya maupun lingkungannya ke arah tercapainya martabat, mutu dan kemampuan manusiawi yang optimal dan pribadi yang mandiri. Kedua, Menurut Mangunhardjana untuk melakukan pembinaan ada beberapa pendekatan yang harus diperhatikan oleh seorang pembina, antara lain:

a. Pendekatan informative (informative approach), yaitu cara menjalankan program dengan menyampaikan informasi kepada peserta didik. Peserta didik dalam pendekatan ini dianggap belum tahu dan tidak punya pengalaman.

b. Pendekatan partisipatif (participative approach), dimana dalam pendekatan ini peserta didik dimanfaatkan sehingga lebih ke situasi belajar bersama.

c. Pendekatan eksperiansial (experienciel approach), dalam pendekatan ini menempatkan bahwa peserta didik langsung terlibat di dalam pembinaan, ini 
disebut sebagai belajar yang sejati, karena pengalaman pribadi dan langsung terlibat dalam situasi tersebut ${ }^{6}$.

\section{Maharatul Kalam ( Kemampuan Berbicara)}

Pada umumnya kompetensi bahasa arab dibagi menjadi empat yaitu: kompetensi mendengar, berbicara, membaca dan menulis. Tetapi penekanan yang menjadi tujuan utama pembelajaran bahasa arab dalam pembinaan ini adalah pada kompetensi berbicara. Adapun kompetensi berbicara atau Keterampilan Berbicara atau (Mahârah Al-Kalâm) adalah kemampuan mengungkapkan bunyi bunyi artikulasi atau kata kata untuk mengespresikan pikiran berupa ide, pendapat, keinginan atau perasaan kepada mitra bicara. Dalam makna yang lebih luas berbicara merupakan suatu sistem tanda yang dapat didengar dan dilihat untuk menyampaikan pikiran dalam rangka memenuhi kebutuhan.

Keterampilan berbicara adalah keterampilan yang paling penting dalam berbahasa. Sebab berbicara adalah bagian dari keterampilan yang dipelajari oleh pengajar, sehingga keterampilan berbicara dianggap sebagai bagian yang sangat mendasar dalam mempelajari bahasa asing. Sedangkan maharah kalam adalah berbicara secara terus-menerus tanpa henti tanpa mengulang kosakata yang sama dengan menggunakan pengungkapan bunyi. Menurut Tarigan; berbicara merupakan kombinasi faktor faktor fisik, psikologis, neurologis, semantik dan linguistik secara luas sehingga dapat dianggap sebagai alat manusia yang paling penting bagi kontrol sosial. Senada dengan pernyataan Tamimullah menjelaskan tentang (Maharatul Kalam) atau keterampilan berbicara bertujuan agar pelajar mampu berkomunikasi lisan secara baik dan wajar dengan bahasa Arab yang mereka pelajari. Berbicara mengandung arti menyampaikan pesan kepada orang lain dalam cara yang secara sosial dan dapat diterima. Keterampilan berbicara (maharah al-kalam/speaking skill) adalah kemampuan mengungkapkan bunyi-bunyi artikulasi atau kata-kata untuk mengekspresikan pikiran berupa ide, pendapat, keinginan, atau perasaan kepada mitra bicara. Dalam makna yang lebih luas, berbicara merupakan suatu sistem tanda-tanda yang dapat didengar dan dilihat yang memanfaatkan sejumlah otot tubuh manusia untuk menyampaikan pikiran dalam rangka memenuhi

\footnotetext{
${ }^{6}$. http://eprints. Jurnal. walisongo.ac.id.
} 
kebutuhannya Namun tentu saja untuk mencapai kepandaian berkomunikasi diperlukan aktivitas pembinaan bahasa arab yang instensif dan mendukung. ${ }^{7}$

\section{Metode Mubasyarah (Metode Langsung)}

Metode langsung memiliki tujuan agar para pelajar/santri mampu berkomunikasi dengan bahasa asing (Arab) yang dipelajarinya seperti orang yang memilik bahasa tersebut. Untuk mencapai kemampuan ini para santri diberikan banyak latihan secara intensif. Latihan latihan ini diberikan dengan asosiasi langsung antara kata kata/kalimat kalimat dengan maknanya, melalui deminstrasi / gerak, mimik muka dsb. Adapun karateristik metode mubasyarah adalah : Pertama, Berbahasa adalah bicara, maka berbicara merupakan aspek yang harus diperioritaskan. Jika materi dalam bentuk bacaan, maka bacaanpun itu pertamakali disajikan secara lisan. Kedua, Sejak dini pelajar dibiasakan berpikir dengan bahasa asing (arab) yang dipelajari. Cara ini dilakukan agar pandai megggunakan bahasa seperti menggunakan bahasa ibu. Ketiga, Bahasa ibu dan bahasa kedua atau terjemahan ke dalam dua bahasa tersebut tidak digunakan karena Tidak terlaku memperhatikan tata bahasa kalaupu ada hanya diberikan dengan mengulang ngulang contoh kalimat secara lisan bukan secara devinisi, Ada asosiasi langsung antara kata dan kalimat dengan makna yang dimaksud melalui peragaan, Untuk memantapkan pelajar dalam menguasai bahasa asing yang dipelajari, mengajar memberikan latihan berulang ulang dengan contoh dan hafalan.

Adapun langkah - langkah penggunaan metode mubasyarah adalah: Pertama, Pendahuluan memuat berbagai hal yang berkaitan materi yang dipergunakan atau yang akan disajikan baik berupa apresiasi atau tes awal tentang materi. Kedua, Guru memberikan materi berupa dialog-dialog pendek dan rileks. Materi ini mula-mula diberikan secara lisan dengan gerakan atau isyarat dengan menggunakan bahasa yang biasa dipakai setiap harinya. Ketiga, Pelajar/santri diarahkan untuk disiplin mendengarkan dialog yang disajikan dan menirukan dialog tersebut sampai lancar. Keempat, Pelajar/santri dibimbing untuk menerapkan dialog tersebut dengan teman-temannya secara berpasangan dan bergiliran. Pelajar

7 . Acep Hermawan, Metodologi Pembelajaran Bahasa Arab, (Bandung: PT Remaja Rosdakarya Offset, 2009), 135. 
yang sudah maju diberikan kesempatan untuk mengadakan dialog lain yang dianalogikan dengan contoh yang diberikan oleh guru. ${ }^{8}$

\section{Strategi pembelajaran Maharatul Kalam dengan Metode Mubasyarah}

Ada beberapa strategi dan tehnik yang dipergunakan dalam meningkatkan latihan Pra-komunikatif dalam pendampingan bahasa arab khususnya keterampilan berbicara Arab dengan metode mubasyarah antara lain:

\section{Al- hifdz ala al-hiwar (Hafalan dialog)}

Tehnik ini merupakan latihan meniru dan menghafalkan dialog- dialog mengenai berbagai macam situasi dan kesempatan. Melalui latihan ini diharapkan santri dapat mencapai kemahiran yang baik dalam berbicara dan percakapan yang dilakukan secara wajar dan tidak dibuat buat.

2. AL-hiwarbil-shuwwar (Dialog melalui Gambar)

Tehnik ini diberikan agar para pelajar dapat memahami fakta melalui gambar yang diungkapkan secara lisan sesuai dengan tingkatan mereka. Dalam hal ini tim akan membawa gambar-gambar dan menunjukkanya satu persatu kepada santri sambil bertanya lalu para santri juga menjawab sesuai gambar yang ditunjukkan.

\section{Al-hiwar al-jama'i (Percakapan kelompok)}

Latihan ini mengharuskan adanya pembagian kelompok-kelompok dan setiap kelompok diberikan judul cerita yang sederhana. Sebelum latihan maka anggota kelompk diperkenankan untuk berunding dengan teman-teman sekelompoknya. Didalam latihan ini para pelajar berganti- ganti mengatakan sesuatu yang disambung oleh teman-teman sekelompoknya sehingga menjadi sebuah cerita yang lengkap. Semua kegiatan percakapan direkam sehingga dapat didengarkan lagi. Dalam hal ini Pembina berkeliling dari satu kelompok ke kelompok lainnya. Setelah kegiatan berakhir maka rekaman tadi dapat diputar kembali dan didiskusikan tentang bagaimana isi, pola, intonasi dan sebagainya.

4. At-tamsil (Bermain peran)

Strategi selanjutnya adalah tehnik bermain peran, dalam hal ini santri diberikan tugas peran tertentu. Mereka akan memerankan beberapa dialog

${ }^{8}$ Hermawan, Metodologi $179-181$ 
berupa percakapan-percakapan sederhana samapi yang sangat rumit yang biasa mereka lakukan setiap harinya. Bermain peran ini merupakan tehnik yang sangat berguna dalam melatih prilaku berbahasa santri.

5. At-ta'birat al - ijtimaiyyah (Pola Ungkapan Sosial)

Ungkapan sosial maksudnya adalah perilaku-perilaku sosial saat berkomunikasi yang diungkapkan secara lisan, misalnya memberi hormat, mengungkapkan rasa kagum, gembira, pujian, ucapan selamat dan sebagainya. Pola-pola ungkapan ini dipraktekkan dalam rangkaian pembicaraan pada situasi tertentu. ${ }^{9}$

\section{B. PEMBAHASAN HASIL}

Adapun hasil penerapan strategi ini dalam pembinaan sebagai berikut:

\section{a. Hifdzul Hiwar (Menghafal Dialog)}

Strategi ini dimulai dengan membaca dan menghafal seluruh kosa kata yang berkaitan dengan tema-tema yang telah ditentukan. Dimulai dengan mendengarkan pengajar secara seksama, agar tidak terjadi salah pengucapan baik itu terkait dengan panjang pendeknya, atau tanda bacanya. Adapun mufrodat( kosa kata ) tersebut terdiri dari isim ( kata benda), fi'il ( kata kerja) dan Hurf ( kata sambung). Setelah semua santri menghafalkannya dengan benar, maka peneliti mulai melakukan tanya jawab untuk meyakinkan apakah hafalannya sudah muqim (tertancap kuat) atau hanya sekedar menghafal saja, tidak lupa arti dari setiap kosa kata yang mereka hafalkan dengan lengkap. Selain tanya jawab, para santri juga maju kedepan teman-temannya untuk menghafalkan kosa kata tersebut secara bergiliran sehingga lebih meyakinkan.

Setelah itu barulah dilakukan pembacaan hiwar (dialog) secara bersamaan. Hal ini dimulai dengan membaca dan diikuti dengan mengartikan Sehingga kalimat perkalimatnya dipahami dengan baik oleh para santri. Setelah itu para santri dipersilahkan untuk membaca ulang apa yang tadi telah mereka artikan. Dan hafalan pun bisa dimulai ketika semua santri telah selesai membaca dan memahami apa yang menjadi isi dari pada materi tersebut. Tim dalam hal ini telah mengcopi modul tersebut sesuai dengan jumlah santri dan

${ }^{9}$ Ibid., 136-142 
santriwati yang ikut dalam pendampingan ini sehingga menghafal menjadi lebih mudah kerena memegang modul masing-masing. Dengan adanya modul ini, konsentrasi menghafal juga menjadi lebih serius dan tidak mengganggu santri lainnya.

Modul telah dirancang dengan sangat sederhana dan sesuai dengan keadaan yang biasa terjadi di lingkungan pondok. Kalimat-kalimat di dalamnya berisi bahasa-bahasa yang acap kali diucapkan oleh santriwan santriwati itu sendiri. Sehingga ini juga akan berdampak terhadap mudahnya hafalan mereka. Tim juga memastikan mereka menghafal secara individual dengan baik. Dan untuk langkah selanjutnya para santri harus mencari pasangan, ini bertujuan agar dialog ( hiwar) yang mereka hafalkan tadi mendapatkan timbal balik terhadap lawan bicara dan dilakukan secara bergantian dan saling bertanya menggunakan pertanyaan pertanyaan yang disediakan di dalam modul tersebut.

b. Al-hiwar al-jama'i (Percakapan kelompok)

Dalam hal ini santriwan dan santriwati dikelompokkan menjadi dua, mereka diberikan kesempatan untuk berdiskusi bersama, dan saling menguatkan hafalannya masing masing. Mereka dipimpin oleh ketua kelompoknya mengartikan ulang dialog-dialog yang sudah mereka hafalkan. Lalu setelah mencapi kesepakatan dan siap maka tim mulai memberikan abaaba agar mempersiapkan diri untuk menjawab pertanyaan-pertanyaan dari kelompok lainnya, dan begitu sebaliknya. Selain pertanyaan tentang dialog, setiap kelompok juga berhak bertanya tentang kosa kata juga sehingga pertanyaannya menajadi bervariasi

Setiap kali melakukan diskusi kelompok maka tim juga selalu memberikan motivasi dan trik-trik belajar bahasa arab agar lebih cepat paham dan tergerak untuk belajar dengan mandiri. Sesekali tim memberikan penghargaan bagi santri dan santriwati yang berani untuk tanpil di depan ataupun yang mampu menjawab pertanyaan temannya dengan jawaban yang benar. Sehingga pembelajaran terasa lebih hidup dan semangat para santri menjadi lebih baik. 
c. At-ta'birat al-ijtimaiyyah (Pola Ungkapan Sosial)

Dalam pendampingan ini juga diajarkan beberapa hal yang sangat penting seperti ungkapan ungkapan social, maksudnya adalah perilakuperilaku sosial saat berkomunikasi yang diungkapkan secara lisan, misalnya memberi hormat, mengungkapkan rasa kagum, gembira, pujian, ucapan selamat dan sebagainya. Pola-pola ungkapan ini dipraktekkan dalam rangkaian pembicaraan pada situasi tertentu. Dan adapun contoh dari ungkapan-ungkapan tersebut seperti: jayyidjiddan( ), ahsanta ( ), anta mumtaz ( ), tahni'ah ( ). Dan ungkapan-ungkapan lain yang senada dengan itu.

d. At-tamsil (Bermain peran)

Dalam hal ini tim mencoba untuk mengatur Strategi lain dalam pengembangan model belajar bagi para santri dan santriwati. Yaitu dengan tehnik bermain peran, dalam hal ini ketika santri membaca dialog atau menghafalnya mereka akan memainkan peran sesuai dengan siapa yang ada dalam dialog. Mereka akan memerankan dialog berupa percakapanpercakapan sederhana (hiwar) sembari menikmati hal tersebut. Bermain peran ini merupakan tehnik yang sangat berguna dalam melatih perilaku berbahasa santri agar tidak kaku dan terkesan jumud dalam berbahasa. Mereka bebas berekpressi dan menyatakan pikiran-pikiran yang mereka ingin tambahkan. Hal ini juga menumbuhkan rasa percaya diri, karena untuk menjadi seorang pemain yang berperan tidaklah mudah, apalagi teks yang sedang dimainkan menggunakan bahasa arab. Sehingga hal ini juga membantu tim untuk mengambil penilaian yang lebih obyektif. Pada akhirnya mereka akan terlatih betul dalam menggunakan bahasa arab.

Beberapa hal yang diperbaiki atau ditambah dalam beberapa dialog (hiwar) yang mereka hafalkan, biasanya berkutat pada penggunaan dhomir dalam fi'il. Bagaimana kalau yang melakukan pekerjaan itu adalah saya sendiri, atau dia, atau kamu atau mereka, atau kita semuanya. Ini akan sangat berpengaruh dalam menentukan bagaimana arti dari dialog itu sendiri. Atau materi tentang Isim (kata benda)yang juga berkaitan dengan berapa banyak benda tesebut. Contoh jika benda itu tunggal maka disebut sebagai( mufrod), jika dua ( mutsanna) dan jika tiga atau lebih disebut ( Jama'). Hal halini 
terlihat sangat sepele, tetapi memberika efek yang sangat besar ketika dikaitkan dengan berbicara bahasa arab. Atau hal tersebut berkaitan dengan jama; muzakkarissalim atau muanatsissalim.

e. AL-hiwarbil-shuwwar (Dialog melalui Gambar)

Dialog melalui gambar ini dimaksudkan untuk memberikan kejelasan kepada santri dan santriwati tentang apa yang mereka pelajari. Dari penampilan gambar yang ada, maka hal tersebut dapat menjadi sebuah media yang menyampaikan pesan dan ditangkap atau dijawab melalui ungkapan verbal. Tetapi karena pembahasan yang menjadi materi dalam pembinaaan ini berputar hanya disekeliling lingkungan pondok pesantren maka hal itu tidak terlalu dibutuhkan, mereka bisa melihat langsung fakta atau kenyataan yang ada disekitar mereka. Sebenarnya tehnik ini akan menggunakan cara dengan membawa gambar-gambar dan menunjukkanya satu persatu kepada santri sambil bertanya lalu para santri juga menjawab sesuai gambar yang ditunjukkan. Tetapi karena mereka dapat melihatnya secara langsung, apalagi tempat dilakukannya pendampingan ini juga salah satu tempat (Mesjid) yang menjadi materi pembelajaran, maka hal ini akan lebih memudahkan santri dan santriwati dalam memberikan pendapat atau menjawab pertanyaan.

\section{EVALUASI}

Untuk mengetahui seberapa jauh penguasaan bahasa arab dalam aspek maharatul kalam ini, tim telah menyediakan form penilaian yang membantu mengukur seberapa jauh penguasaan materi yang diberikan, seberapa lancar mereka berbicar dan seberapa banyak hafalan mufrodatnya. Setiap poinya diberikan nilai yang sesuai dengan kemampuan yang dicapai oleh santri atau santriwati yang mengikuti pendampingan ini. Dan sejauh ini dari hasil penilaian yang telah dilakukan oleh tim maka didapatkan pencapaian yang cukup baik dari segi mahkraj, kelancaran dan hafalan yang telah mereka lakukan. Penilaian ini juga diambil melalui proses keaktifan, kesungguhan dan partisipasi ketika belajar. Penilaian difokuskan secara lisan karena berkaitan dengan bagaimana mereka berbicara. Berikut adalah point-point penilaian 
maharatul kalam dan diskripsi penilaian yang diperoleh selama pendampingan ini:

Setelah melalui proses pendampingan dengan baik, maka berangsur angsur para santri dan santriwati mulai menggunakan bahasa arab yang walaupun tercampur dengan bahasa Bima. Ketika bertemu dan saling sapa, mereka mampu mengutarakannya ke dalam bahasa arab dengan baik dan benar.

Adapun perbedaan hasil yang didaptkan sebelum dan sesudah kegiatan ini adalah:

\begin{tabular}{|c|c|c|}
\hline No & $\begin{array}{l}\text { Keadaan santri sebelum } \\
\text { pendampingan }\end{array}$ & $\begin{array}{l}\text { Keadaan santri setelah } \\
\text { pendampingan }\end{array}$ \\
\hline 1 & $\begin{array}{l}\text { Semua Santri menggunakan } \\
\text { bahasa Bima ketika belajar }\end{array}$ & $\begin{array}{l}16 \text { dari } 20 \text { santri } \text { mulai } \\
\text { menggunakan bahasa arab secara } \\
\text { aktif pada saat belajar }\end{array}$ \\
\hline 2 & $\begin{array}{l}\text { Hafalan mufrodat semua santri } \\
\text { masih terlalu sedikit. Bahkan } \\
\text { ketika dites dari } 20 \text { santri yang } \\
\text { mengikuti pendampingan ini } 10 \\
\text { orang santri tidak hafal mufrodat } \\
\text { sama sekali }\end{array}$ & $\begin{array}{l}\text { Dari } 20 \text { santri yang mengikuti } \\
\text { kegiatan ini, maka sudah ada } 18 \\
\text { orang yang telah lancar sekali } \\
\text { menghafal mufrodat lengkap } \\
\text { dengan artinya. }\end{array}$ \\
\hline 3 & $\begin{array}{l}\text { Hanya } 5 \text { dari } 20 \text { orang santri } \\
\text { yang memiliki pemahaman yang } \\
\text { cukup baik terhadap hiwar yang } \\
\text { ada didalam modul }\end{array}$ & $\begin{array}{l}18 \text { orang dari } 20 \text { orang santri } \\
\text { mampu memahami hiwar dengan } \\
\text { cukup baik }\end{array}$ \\
\hline 4 & $\begin{array}{l}\text { Hanya } 5 \text { dari } 20 \text { orang santri } \\
\text { yang mampu menggunakan } \\
\text { bebeapa kalimat didalam hiwar }\end{array}$ & $\begin{array}{l}\text { Dari } 20 \text { orang santri yang } \\
\text { mengikuti kegiatan ini hampir } 17 \\
\text { orang yang mampu menggunakan } \\
\text { kalimat kalimat di dalam hiwar }\end{array}$ \\
\hline 5 & $\begin{array}{l}\text { Terdapat hampir } 15 \text { orang santri } \\
\text { yang jarang berkomunikasi } \\
\text { untuk menjawab dan bertanya }\end{array}$ & $\begin{array}{l}\text { Semua santri berusaha } \\
\text { berkomunikasi, menjawab atau } \\
\text { bertanya dengan baik dan benar. }\end{array}$ \\
\hline
\end{tabular}




\section{KESIMPULAN}

Bahwa kegiatan pendampingan bahasa Arab aspek maharatul kalam dengan metode mubasyarah ini berjalan dengan baik dan efektif, hal ini ditunjukkan oleh semangat santriwan dan santriwati yang sangat tinggi dalam belajar, materi yang telah disusun rata rata tersampaikan dengan baik, penguasaan terhadap hafalan hiwar dan mufrodat juga sangat tingggi. Dengan pembelajaran bahasa arab spesifikasi maharatul kalam ini sangat membantu santri memahami materi lebih cepat, sehingga memberikan pengaruh dan semangat tersendiri ketika belajar berbicara bahasa arab pada saat pendampingan berlangsung.

\section{DAFTAR PUSTAKA}

Al Farisi M. Zaka, 2014. Pedoman penerjemahan Arab-Indonesia, Bandung: Remaja Rosdakarya.

Andriani Asna, 2015. Urgensi Pembelajaran Bahasa, TA’ALLUM,Vol. 03, No. 01, Juni

Hermawan Acep, 2014. Metodologi pembelajaran bahasa arab, Bandung: RemajaRosdakarya.

Zuhriyah Nurul, 2018. Konsep Arba'ah Al-Mahârât al-Lughât Dalam Pembelajaran Bahasa Arab, Al-Af'idah, Volume II, Nomor I Januari.

Sudrajat dan M. Subhan, 2001. Penelitian Kualitatif, Jakarta: Cahaya Pena.

Nailurrahmawati dan Fathul Mujib, 2011. Metode permainan edukatif dalam bahasa arab, Jogjakarta: Diva Press.

Narkubo Cholid, 2003 Metodologi Penelitian, Jakarta: Bumi Aksara 